\title{
EVALUATIONS OF REVIEWER PORTALS AND STANDARDS IN THE HOSPITALITY INDUSTRY - INFLUENCE ON QUALITY VALORISATION
}

\author{
OCJENE RECENZIJSKIH PORTALA I STANDARDI U HOTELIJERSTVU - \\ UTJECAJ NA VREDNOVANJE KVALITETE
}

\author{
Assistant Professor Tamara Floričić, PhD \\ E-mail: tfloricic@unipu.hr
}

\author{
Nina Pauletić \\ Juraj Dobrila University of Pula, \\ Faculty of Economics and Tourism "Dr. Mijo Mirković", \\ Preradovićeva 1, HR - 52100 Pula, Hrvatska/Croatia
}

UDK/UDC: 005.6:338.486.3

JEL klasifikacija/JEL classification: L15; Z32

DOI: $10.30657 /$ hdmk.2020.25

Prethodno priopćenje/Preliminary communication

Jezik/Language: Engleski/English

\begin{abstract}
Quality and standards are key segments of the formed hospitality service for realisation of guest satisfaction with all its aspects and for affirmation of future demand. In view of the development of modern hospitality and when looking at it through a prism of responsible mass tourism, continuous investment in the quality and in standard updates is needed, as they are the key that leads towards success. The focus of this research is on international standards and performance indicators of hotel housekeeping and on their perspective in Croatian hospitality, with analytics of grading of hotel quality and guest satisfaction with hospitality services in TripAdvisor. The research was conducted for the purposes of valorisation of the connection between realised indicators of work involvement with realised grades and satisfaction of consumers, tourists. The purpose itself of this paper is reflected in the set goal and is outlined in the form of the question: How much does the amount of involved work affect the realised quality and what are the future recommendations? With aspects of valorisation of elements of hospitality service, they represent a contribution to the research and to quality improvement science. Supported by the qualitative and quantitative methodologies, the research conclusions represent a platform for future consideration of the relevance of "soft skills", given that the quality in hospitality mirrors the way in which people work, skills they have and which they are continuously improving through targeted education of lifelong learning and the manner in which they perceive their consumers.
\end{abstract}

Key words: quality in hospitality, services, hotel housekeeping, standards, TripAdvisor portal. 


\section{INTRODUCTION}

Within the hospitality industry, hotel trade represents a service business with a high share of fixed assets as the hardware and human labour as the software value chain components. It is very important human factor that ennobles hospitality service by personal communication at all levels. Professionalism, empathy, understanding, safety, reliability and respect are the characteristics which, besides the skills which are required for specific professional segments in hospitality, make all the difference in evaluation and choice of hotels and represent the quality core itself. As tourism is becoming a leading world industry, the number of hotels which fight for every guest is correspondingly also increasing and, through market competitiveness, as the essence of different hospitality service dimensions, business categories are realised, and a new development flywheel is affirmed.

Quality and standards are an important part of hospitality. They condition the way in which delivery of services and designed services are provided for the purposes of achieving guest satisfaction, their repeated visit and attraction of new guests. Given the development of modern hospitality within the system of mass tourism, the importance is recognised of continuous investment in the quality and standard updates, as they are the ones which lead towards success and success itself is assessed through guest satisfaction grades. The problem area of this paper lies in international labour standards, rules and indicators of hotel employee work productivity, as well as in evaluation of the influence of the service assessment segment on the overall grade for hotel guest satisfaction. The paper explores empirically five Croatian hotels, differentiated by their size and, with new knowledge, contributes to the understanding of the conjunction of work standards and quality assurance and evaluation of reviewer Internet portals. As the most powerful reviewer portal, TripAdvisor classifies the evaluated quality aspects into hotel location, hotel cleanliness, for which hotel housekeeping is responsible, levels of quality of delivered services and the overall grade of the perceived value.

There are several ways in which to measure the achievement of quality, including the TQM methodology, which is more directed towards products, to the SERVQVAL model of measurement of service quality (SERVices QUALity Model). ${ }^{1}$ According to the revenue management innovative techniques and methods, by which prices and income are managed in line with hotel occupancy rates, new dynamic concepts of planning of the number of employees for the purposes of optimal provision of quality services and work productivity are presented. Modern technologies facilitate direct online evaluation of hotel services, both when it concerns its overall value and specific segments. Consideration of the link between the grades for the housekeeping segments and the number of engaged chamber maids represents knowledge, but it also opens new questions related to work productivity and efficiency in the hotel industry.

\section{QUALITY IN HOSPITALITY - THEORETICAL GUIDELINES}

In the century of globalisation and hyper competitiveness, organisations have suddenly become exposed to the global market. Consequently, their competitiveness were no longer geographically close organisations, but also those from all other parts of the world. Those organisations which have fewer problems with their competition have reached a higher level of quality in their processes. Only the organisations which are capable of producing products of world quality can compete at this level, stresses. ${ }^{2}$ In consideration of quality in tourism and hospitality, Avelini Holjevac points out that the quality is a complex concept, composed of

\footnotetext{
${ }^{1}$ Valarie A. Zeithamal, A. "Parsu" Parasuraman and Leonard L. Berry, Delivering Quality Service - Balancing Customer Perceptions and Expectations, The Free Press, New York, 1990, pp. 20-21.

${ }^{2}$ Tonći Lazibat, Upravljanje kvalitetom, Znanstvena knjiga, Zagreb, 2009, str. 13.
} 
several elements or criteria. ${ }^{3}$ Quality elements or criteria emanate from quality essence of different types of products, services, activities, i.e. depending on their use, usefulness and importance for the buyer - consumer.

Measurement of quality elements does not have a generally adopted model, nor are there measurement methods, but it can be observed according to users' perception about service quality. Berry et al. emphasise ten main quality characteristics: ${ }^{4}$

- Reliability in service provision (fulfilling of promises given to users, quality service provision from the very first attempt, consistency in service provision);

- Business responsibility (timely actions, employee preparedness and availability to provide needed services);

- Competence (level of knowledge and skills required for service provision, contact staff competence);

- Accessibility (service availability - convenient company opening hours, location);

- Warm hospitality (staff kindness, respect, understanding, friendly manner);

- Communication with users (provision of information to users in, for them, understandable manner, collection and consideration of users' opinions, comments and suggestions);

- Credibility (fairness, professionalism, image and confidence which the company has);

- Safety (removal of possibility of danger, risk reduction, financial security, guarantees);

- Tangible elements (exterior and interior, employee appearance, promotional materials)

Further to this, Kandampully explores guest differentiated expectations in the perception of quality, stating that quality means a different thing for different people at different times and in different circumstances. ${ }^{5}$ Zeithamal et al. do the same. ${ }^{6}$ Through a formed model of the relationship between quality and expectation, in the research focus they place "excellent service", as well as the possibilities of its delivery. They emphasise quality attributes: reliability, empathy, responsibility and tangible values. Monroe ${ }^{7}$ deals with consumer quality and expectations, while Rodrigues et al. and Brotherton and $\mathrm{Wood}^{8}$ explore measurement systems, at the same time developing the Zithamal et al.'s model.

In consideration of quality, the importance of the tourism system "software" human factor component is emphasised. Work quality and a company's business success are based on management's self-confidence and confidence in all employed, as well as the confidence of all employed in management structures. Investment in technology, equipment and process changes are very important, but those inputs do not ensure the business growth and advantage

\footnotetext{
${ }^{3}$ Ivanka Avelini Holjevac, Upravljanje kvalitetom u turizmu i hotelskoj industriji, Fakultet za turistički i hotelski menadžment, Opatija, 2002, str. 12.

${ }^{4}$ Leonard L. Berry, Valarie A. Zcithaml, A. „Parsu” Parasuraman, "Quality Comes in Services, too" objavljeno u Christopher H. Lovelock, Managing Services Marketing, Operations and Human Resources, Prentice-Hall International, Englewood Cliffs, NJ, 1988, p. 216-225

5 Jay Kandampully, Connie Mok and Beverley Sparks, "Service Quality Management in Hospitality", Tourism and Leisure, The Haworth Hospitality Press, New York, 2001, pp. 144

${ }^{6}$ Valarie A. Zeithamal, A. "Parsu" Parasuraman and Leonard L. Berry, Delivering Quality Service - Balancing Customer Perceptions and Expectations, The Free Press, New York, 1990, pp. 20-21.

${ }^{7}$ Calvin Monroe, Challenging in Delivering Quality Services: Balancing Customer Expectations, Grin Verlag, Germany, 2014.

${ }^{8}$ Lewlyn L. R. Rodrigues, Anisa Hussain, U. Syed Aktharsha, Girish K. Nair, 2013, Service quality measurement: issues and perspectives, Anchor academic publishing, Germany Brotherton, Robert Brothertoon and Roy C. Wood, The SAGE handbook of hospitality management, SAGE publications Ltd, London, UK, 2008.
} 
before competition without a corresponding investment in people. Avelini Holjevac ${ }^{9}$ points out that service quality represents a crucial determinant of competitiveness and a key to improvement of profitability and not the business cost. Continuous education and affirmation of knowledge are essential for realisation of continuity of staff performance, their satisfaction and motivation. Namely, full quality management is based on teamwork and only with the required knowledge can everyone be creative and efficient and contribute to increase in work quality and company performance. ${ }^{10}$ Profit, as an ultimate hotel business goal, represents an economic aspect of quality assurance. Implementation of a full quality management system has its economic justification only if income becomes greater, costs are reduced, and profit is increased. Moreover, TQM, as an integral quality management system, is based on the concept of permanent process enhancement and improvement, on constant quality and teamwork, all of which have as a result continuous progress, from quality and product improvement, customer satisfaction, strengthening of market competitiveness with reduction of business costs. Accordingly, the quality of management is increased, as well as the hotel image in the market. The problem area of quality ranking and evaluation is closely linked to hotel categories and consumer expectations which are fulfilled by specific category hotels. In the product marketing matrix, prices, promotion and distribution it is therefore important to develop the strategies of market product segmentation and positioning in order for the expected values to be compatible with the ones that a hotel can actually deliver.

Work productivity, which is the result of the ratio of realised services and invested labour in quantity and quality, points to the importance of consideration of input dimensions, represented by invested resources, of the output, expressed by sales services and quality, which is perceived and paid for by consumers and which is reflected through the satisfaction level and gained experiences. Avelini Holjevac emphasises the factors which affect work productivity: salaries and bonuses, education, motivation and training, work conditions, work planning and organisation, moral and culture and work standards. ${ }^{11}$ They are differentiated by the following standards: quantity, quality, time, costs and ethical standards. As the relationship between the standards of quality and standards of quantity is the subject of the study and a platform for research implementation the review follows of standards in hotel housekeeping in the international hotel industry.

\subsection{Importance of standards in hospitality}

Standardisation is a specific procedure of determination of identical properties of materials, parts, assemblies and final products concerning dimensions, quality forms, i.e. physical or chemical properties which that material, part, assembly or final product - service must have. Standardisation is a process of adaptation and implementation of standards, technical and quality regulations. ${ }^{12}$ As a proscribed quality, standards contribute to simplification of business processes and procedures, as well as a product's physical characteristics, facilitate easier communication between interested parties, raise the general level of business cost-effectiveness, lower production costs, protect people's health and lives, protect consumer interests and natural and work environments. ${ }^{13}$

\footnotetext{
${ }^{9}$ Ivanka Avelini Holjevac, Upravljanje kvalitetom u turizmu i hotelskoj industriji, Fakultet za turistički i hotelski menadžment, Opatija, 2002, str. 12.

${ }^{10}$ Branko Blažević, Turizam u gospodarskom sustavu, Sveučilište u Rijeci, Fakultet za turistički i hotelski menadžment, Opatija, 2007, str. 262.

11 Ivanka Avelini Holjevac, „Povećanje kvalitete i produktivnosti u hrvatskoj hotelskoj industriji - uvjet za povećanje konkurentnosti na svjetskom turističkom tržištu“, Zbornik radova Kvaliteta i konkurentnost, Hrvatsko društvo za kvalitetu, Zagreb, 2004.

${ }^{12}$ Fikreta Bahtijarević Šiber i Pere Sikavica, Leksikon menadžmenta, Masmedia, Zagreb, 2001, pp. 534.

13 Zdenko Cerović, Hotelski menadžment, Fakultet za turistički i hotelski menadžment, Opatija, 2003, pp. 135.
} 
Standardisation is a complex and continuous process which is subject to improvements and which cyclically encompasses the standardisation process from prescription of standards, education and training of employees of all hotel departments, implementation of prescribed standards in practice, constant controls and removal of deviations and standard improvements.

In the hotel industry, work standards in a wider sense represent a set of different rules by which requirements are regulated concerning the time needed for specific jobs, performance quality, behaviour at work (towards guests and towards other colleagues), dress code, required education and skills for specific jobs, work ethics, etc.; they are the main conditions which are needed for achievement of certain quantity and quality of hotel products and services. In a narrower sense, work standards prescribe basic work elements: quantity, quality, time and costs and are, accordingly, made up of several individual standards of quantity, quality, time, costs and ethical standards.

The analysis of staff scope consists of determination of the total number of employees and evaluation as to whether that number corresponds to the overall business result and hotel performance. In this, it is primarily necessary to determine the average. It represents the dimension which defines the optimal relationship between the business result and the number of employees, as well as the hotel capacity and the number of employees. ${ }^{14}$ As an average, the following standard relationships can be used: realised income per employee, realised number of overnights per employee, realised profit per employee and work regulations/standards. Illustration of the hotel industry work standards follows in Table 1.

Table 1: European average of hotel structure of full-time employees per one hundred available rooms

\begin{tabular}{|l|r|r|}
\hline \multicolumn{1}{|c|}{ Departments - coefficient } & Number of staff per 100 rooms & Number of staff per 1 room \\
\hline Reception & 10.1 & 0.10 \\
\hline Housekeeping & 12.9 & 0.13 \\
\hline Food and beverage & 34.6 & 0.35 \\
\hline Telephone & 1.5 & 0.02 \\
\hline Smaller business units & 2.5 & 0.03 \\
\hline Administration & 6.3 & 0.06 \\
\hline Marketing - sales & 1.5 & 0.02 \\
\hline Marketing - other & 0.4 & 0.04 \\
\hline Maintenance and repairs & 3.3 & 0.03 \\
\hline Other jobs & 3.9 & 0.04 \\
\hline Total & 77.0 & 0.77 \\
\hline
\end{tabular}

Source: Authors' processing according to: Worldwide hotel industry, Horwath and Horwath International New York, 1998.

The presented international work standards will form a basis for evaluation of business performances in the consecutive research.

\subsection{Modern technologies in quality assessment - reviewer portals}

Launched in 2000, TripAdvisor is an Internet portal, which deals with tourist reviews and recommendations and which, using a meta search engine, enables hotel bookings.

\footnotetext{
${ }^{14}$ Ivanka Avelini Holjevac, Upravljanje kvalitetom u turizmu i hotelskoj industriji, Fakultet za turistički i hotelski menadžment, Opatija, 2002, str. 12.
} 
However, its main influence in the international tourism market is evidenced in its collection of over 190 million grades and reviews. The portal reviews include 4.4 million hospitality facilities, of which almost 1 million are hotels. The portal has 315 million single visitors per month and 70 million members throughout the world. There are 190 reviews on the portal, and it yields over one billion USD per year (in 2013, the income was 944.7 million USD). ${ }^{15}$ On its website, TripAdvisor collects advertisements for accommodation from over 200 other online portals, compares the hotel and room prices and facilitates bookings. The power of reviewer portals as reliable tools which have an important role in consumer decision making is recognised by the hotel industry and hotels develop different strategies and activities for communication with guests, regardless of whether they left good or bad reviews on the portal ${ }^{16}$ and, given that a considerable effect is recognised on hotel income ${ }^{17}$ Reputation management in hotels is important for many reasons; quality responses to reviews assure guests that their comments have been taken with consideration and that all efforts are made to correct negative elements or to reward positive activities.

In the system of quality assessment, TripAdvisor shows qualitative (reviews, photographs) and quantitative indicators (grades 1-5 for specific service segments: location, cleanliness, service, value and overall score). The portal provides a variety of useful information about the destination, attractions and hospitality facilities, as well as distances from the hotel.

\section{EVALUATIONS OF REVIEWER PORTALS AND STANDARDS IN THE HOSPITALITY INDUSTRY - INFLUENCE ON QUALITY VALORISATION - RESEARCH AND DISCUSSION}

In order for hotels to, like other companies, continually perform well, there is a need for an array of areas which will cooperate and, ultimately, bring best results to hotels. To gain revenue that is bigger than expenditure to pay for the necessary due liabilities, reward their employees and create a profit which will ensure a satisfactory level of returns on the invested means to owners and investors. One of these areas are available human resources. Using those resources and investing in their quality are the main factors of development. Education increases economic competitiveness by assurance of the necessary human resource quality. It facilitates acquisition of knowledge, skills, attitudes and values which individuals need to realise work and social roles. Using a quality workforce, hotels can provide the levels of satisfaction and service quality they are aiming for and obtain the required profits.

Guests give the final grade for hotel quality. Hotels always invest a lot of time and effort in order for guests to be as well satisfied as possible and to, at the end of their stay, complete the surveys with the best grades, both at the hotel and by posting their reviews on the Internet. This research was conducted using TripAdvisor, a renowned Internet portal, which represents a reputable hotel benchmarking tool and offers individual pieces of advice for users who are planning their holiday. On their webpages, there are also suggestions and evaluations of guests who stayed in a specific destination and who share their experiences, making it easier for other guests with the choice of their holiday destinations.

Within the research, which was specially constructed and designed for this topic, 5 hotels were observed according to their offer, both when it comes to accommodation and

\footnotetext{
15 https://megabooker.hr/tripadvisor-za-hotele/, (Pristup: 9.12.2019).

${ }^{16} \mathrm{https}$ ://searchengineland.com/how-the-hospitality-industry-should-approach-online-reviews-and-citations-305374, (Pristup 20.11.2018.).

${ }^{17}$ Laura Badiu, Know Your Business - How Reputation Management Can Help Increase a Hotel's Revenue, $2018 \mathrm{http} / / /$ resources.trustyou.com/c/bl-reputation-management-revenue? $\mathrm{x}=\mathrm{ZoJaVP}$, (Prstup 20.11.2018).
} 
different offers. The said offers also include accessory services, services of food and beverage and additional services, such as specially organised excursions or stays in wellness and spa centres.

The hotels included are: Bozica in Dubrovnik, followed by Marul in Split, Adriatic in Rovinj, Crystal in Poreč and Molindrio in Plava Laguna, Poreč. Guests' comments and their grades regarding the quality of services provided during their stay in those hotels were collected. The observed reviews were from the previous summer months and, for each hotel, a sample of 30 latest reviews was taken.

Table 2: Hotel evaluation - capacity, staff employed by department and reviewer portal TripAdvisor grades

\begin{tabular}{|l|c|c|c|c|c|}
\hline & Hotel A & Hotel B & Hotel C & Hotel D & Hotel E \\
\hline Category & $4 *$ & $4 *$ & $4^{*}$ & $4 *$ & $4^{*}$ \\
\hline Type of hotel & Small & Small & Small & Big & Big \\
\hline Number of rooms & 26 & 14 & 18 & 223 & 265 \\
\hline Number of beds & 46 & 36 & 45 & 443 & 482 \\
\hline Number of chamber maids & 4 & 4 & 4 & 16 & 15 \\
\hline Number of receptionists & 3 & 4 & 6 & 5 & 5 \\
\hline Number of waiters & 7 & 3 & 15 & 21 & 23 \\
\hline Reviews & & & 419 & & 508 \\
\hline Room grades & 4.2 & 4.1 & 4.3 & 3.5 & 3.5 \\
\hline Location grades & 4.4 & 4.8 & 4.8 & 4.2 & 4.4 \\
\hline Service grades & 4.5 & 4.8 & 4.8 & 4.6 & 4.3 \\
\hline Overall grades & 4.5 & 4.5 & 4.5 & 3.9 & 4.0 \\
\hline Difference: rooms/total & $-7 \%$ & $-9 \%$ & $-5 \%$ & $-11 \%$ & $-12.5 \%$ \\
\hline
\end{tabular}

Source: Author's processing.

The Table 2 results represent the main hotel characteristics and staff employed in the hotel key departments and form a basis for further research which puts into the calculation the hotel size and which evaluates the number of employees in relation to the international standard.

Table 3: Table of standards and grade evaluation

\begin{tabular}{|l|r|r|r|r|r|}
\hline & $\begin{array}{c}\text { Number of rooms } \\
\text { per chamber maid }\end{array}$ & $\begin{array}{c}\text { Average of chamber } \\
\text { maids per room }\end{array}$ & $\begin{array}{c}\text { Deviation from } \\
\text { international average }\end{array}$ & $\begin{array}{c}\text { 2 average } \\
\text { cleanliness grades }\end{array}$ & $\begin{array}{c}\text { Overall } \\
\text { grade }\end{array}$ \\
\hline Hotel A & 6.5 & 0.15 & +0.02 & $4.2 / 4.1$ & 4.5 \\
\hline Hotel B & 3.5 & 0.29 & +0.16 & $4.1 / 4.4$ & 4.5 \\
\hline Hotel C & 4.5 & 0.22 & +0.09 & $4.3 / 4.3$ & 4.5 \\
\hline Hotel D & 13.9 & 0.07 & -0.06 & $3.5 / 3.6$ & 3.9 \\
\hline Hotel E & 17.6 & 0.06 & -0.07 & $3.5 / 3.3$ & 4.0 \\
\hline
\end{tabular}

Source: Author's processing.

From the comprehensive data it is possible to note that hotels with a fewer number of rooms, i.e. small hotels, were awarded much higher grades than the big hotels. For example, hotel A with 26 rooms scored an overall grade of 4.5, while hotel D scored the grade of 3.9 and 
it has a total of 223 rooms, which is almost 9 times more rooms. Also, the fewer number of chamber maids per room, the lower the quality. This is best seen from the example of hotel B, where there is a total of 0.29 chamber maids per room, i.e. there are 4 chamber maids on 14 rooms, while hotel $\mathrm{E}$ is in the worst position with 0.06 chamber maids per room, i.e. there are only 15 full-time chamber maids on 482 rooms.

Table 4: Evaluation of number of employed in relation to international hotel standards

\begin{tabular}{|l|r|r|r|r|r|r|}
\hline & \multicolumn{2}{|c|}{ Chamber maids } & \multicolumn{2}{c|}{ Receptionists } & \multicolumn{2}{c|}{ Waiters } \\
\hline & Excess staff & Staff shortage & Excess staff & Staff shortage & Excess staff & Staff shortage \\
\hline Hotel A & & 0.65 & & 0.4 & 1.99 & 1.8 \\
\hline Hotel B & & 2.2 & & 2.6 & 8.7 & \\
\hline Hotel C & & 1.68 & & 17.3 & & 56.1 \\
\hline Hotel D & & 12.76 & & 21.5 & & 68.6 \\
\hline Hotel E & & 19.2 & & & & \\
\hline
\end{tabular}

Source: Author's processing.

In relation to the standards which are listed in accordance with the European average of the structure of full-time hotel employees per one hundred available rooms, the position of staff in hotels was calculated and it is evident that there is a shortage of staff in all categories. As hotel capacities grow, there is greater shortage of workers, while the only excess staff appears in hotels A, B and C, in the waiter category. Within the research context, the problem area of seasonal workers stands out, as, by employing them, the quality positions change, and this represents a platform for further research.

\section{CONCLUSION}

The connection between the grades in reviewer portals and the number of engaged personnel - staff in specific hotel sectors, namely hotel housekeeping departments. Although it concerns the same category hotels which should provide a certain quality standard, a deviation is evidenced which was conditioned by engagement of employees in performance of work tasks. A lower number of employees, i.e. a higher level of work engagement of the same staff which surpasses the norms of the international standard affects the lower grades for guest satisfaction with the quality of the listed service. Future research is suggested using deeper statistical analytics which will prove numerical values and implication of deviation and in which seasonal workers should also be included and engaged. Research limitations were found in the data collection process, although a larger number of hotels were contacted, very few were prepared to present their human resources strategies and standards, although the knowledge gained from the conducted research could benefit their overall business excellence and competitiveness.

\section{Sažetak:}

OCJENE RECENZIJSKIH PORTALA I STANDARDI U HOTELIJERSTVU UTJECAJ NA VREDNOVANJE KVALITETE

Kvaliteta i standardi ključni su segmenti formirane ugostiteljske usluge u cilju realizacije zadovoljstva gosta svim njenim aspektima te afirmacije buduće potražnje. S obzirom na razvoj modernog ugostiteljstva te promatrajući isto kroz prizmu odgovornog masovnog turizma treba kontinuirano 
ulagati u kvalitetu i ažurirati standarde jer oni su ključ koji vodi prema uspjehu. Fokus ovog istraživanja je na međunarodnim standardima i pokazateljima učinkovitosti rada hotelskog domaćinstva te sagledavanju realizacije istih $u$ hrvatskom hotelijerstvu uz analitiku ocjena kvalitete hotela $i$ zadovoljstva gostiju ugostiteljskom uslugom na Tripadvisoru. Istraživanje je provedeno u cilju vrednovanja povezanosti realiziranog pokazatelja angažiranosti rada uz realiziranu ocjenu $i$ zadovoljstvo potrošača, turista. Sama svrha rada reflektira se iz postavljenog cilja i ističe u obliku pitanja: Koliko količina angažiranog rada utječe na realiziranu kvalitetu i koje su buduće preporuke? Iste, uz aspekte vrednovanja elemenata ugostiteljske usluge predstavljaju doprinos istraživanja $i$ unaprjeđenja znanosti o kvaliteti. Podržani kvalitativnom i kvantitativnom metodologijom zaključci istraživanja predstavljaju platformu za buduća promišljanja o važnosti „,soft skills “ vještina, obzirom da kvalitetu u ugostiteljstvu predstavlja način na koji ljudi rade, vještine kojima raspolažu i koje kontinuirano usavršavaju putem ciljanih edukacija cjeloživotnog obrazovanja te način na koji percipiraju svoje potrošače.

Ključne riječi: kvaliteta u hotelijerstvu, usluge, hotelsko domaćinstvo, standardi, portal Tripadvosor.

\section{LITERATURE}

1. Avelini Holjevac, Ivanka, Upravljanje kvalitetom u turizmu i hotelskoj industriji, Fakultet za turistički i hotelski menadžment, Opatija, 2002, p. 12

2. Avelini Holjevac, Ivanka, Povećanje kvalitete i produktivnosti u hrvatskoj hotelskoj industriji - uvjet za povećanje konkurentnosti na svjetskom turističkom tržištu, Zbornik radova Kvaliteta i konkurentnost, Hrvatsko društvo za kvalitetu, Zagreb, 2004.

3. Badiu, Laura, _Know Your Business - How Reputation Management Can Help Increase a Hotel's Revenue, 2018, http://resources.trustyou.com/c/bl-reputation-managementrevenue? $\mathrm{x}=\mathrm{ZoJaVP}$, accessed on 20.11.2018

4. Bahtijarević Šiber, Fikreta i P. Sikavica, Leksikon menadžmenta, Masmedia, Zagreb, 2001.

5. Berry, L. L., Zcithaml, A. Valarie, Parasuraman, A., "Quality Comes in Services, too" objavljeno u Lovelock, C. H, "Managing Services Marketing, Operations and Human Resources", PrenticcHall International, Englewood Cliffs, NJ, 1988.

6. Blažević, B., Turizam u gospodarskom sustavu, Sveučilište u Rijeci, Fakultet za turistički i hotelski menadžment, Opatija, 2007.

7. Cerović, Z., Hotelski menadžment, Fakultet za turistički i hotelski menadžment, Opatija, 2003.

8. https://searchengineland.com/how-the-hospitality-industry-should-approach-online-reviewsand-citations-305374, (Pristup 20.11.2018.).

9. https://megabooker.hr/tripadvisor-za-hotele/, (Pristup) 9.12.2019-

10. https://www.hospitalitynet.org/opinion/4090732.html, Do This To Gain Instant Trust With Hotel Website Visitors, accessed on 20.11.2018.

11. Kandampully, J., Mok, Connie, Beverley Sparks, „Service Quality Management in Hospitality“, Tourism and Leisure, The Haworth Hospitality Press, New York, 2001.

12. Lazibat, T., Upravljanje kvalitetom, Znanstvena knjiga, Zagreb, 2009.

13. Marković, Suzana, „Kvaliteta usluga u hotelskoj industriji: koncept i mjerenje“, Tourism and hospitality industry, Vol. 11, No. 1, Opatija, 2005.

14. Rodrigues, L. L. R., Hussain, Anisa, Aktharsha U.S.and G. Nair, Service quality measurement: issues and perspectives, Anchor academic publishing, 2013, Germany and Brotherton, B., Wood, R. C., The SAGE handbook of hospitality management,SAGE publications Ltd, London, UK, 2008-

15. Zeithamal, A. Valerie, „Parsu“ Parasuraman, A. and L. L. Berry, "Delivering Quality Service - Balancing Customer Perceptions and Expectations", The Free Press, NewYork, 1990. 